Georgetown University Law Center

Scholarship @ GEORGETOWN LAW

2004

\title{
The Politics of (Mis)recognition: Islamic Law Pedagogy in American Academia
}

Lama Abu-Odeh

Georgetown University Law Center, la34@law.georgetown.edu

This paper can be downloaded free of charge from:

https://scholarship.law.georgetown.edu/facpub/39

52 Am. J. Comp. L. 789-824 (2004)

This open-access article is brought to you by the Georgetown Law Library. Posted with permission of the author. Follow this and additional works at: https://scholarship.law.georgetown.edu/facpub

Part of the International Law Commons, and the Legal Education Commons 


\section{GEORGETOWN LAW Faculty Publications}

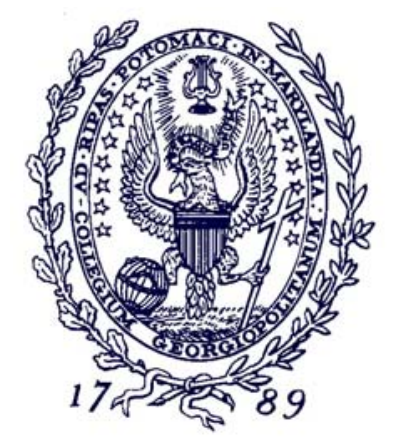

January 2010

\section{The Politics of (Mis )recognition: Islamic Law Pedagogy in American Academia}

52 Am. J. Comp. L. 789-824 (2004)

Lama Abu-Odeh

Professor of Law

Georgetown University Law Center

la34@law.georgetown.edu

This paper can be downloaded without charge from:

Scholarly Commons: http://scholarship.law.georgetown.edu/facpub/39/

Posted with permission of the author 


\section{LAMA ABU-ODEH*}

\section{The Politics of (Mis)recognition: Islamic Law Pedagogy in American Academia}

[C]omparative law has not normally been "transnational" at all, but rather it has grown within the frameworks of different legal traditions, responding to "inner" needs of legal elites. From this point of view a first unexpected project that can be pursued by comparativism is "insulation." This strategy has been peculiarly pursued in Britain, where the distinction between a Common law and a Civil law has been used to "create" and defend a national identity in the field of the law. But the same "insulation" project has been used by socialist lawyers to maintain a felt separation of socialist countries from the rest of the world. A project purported also by "Western" specialists with a strong professional interest in defining the peculiar subject of Soviet Studies as one discipline within the Western academic world.

Pier Giuseppe Monateri, The 'Weak Law':

Contaminations and Legal Cultures ${ }^{1}$

To sum up, Arab law today is a composite of: (1) a residual of Islamic law rules, whether in modern statutory form, as is the case with the laws of domestic relations, or in its classical form applicable in Saudi Arabia as the common law of the land where no statutory legislation exists, (2) the European-based codes, which constitute the backbone of the law in the private and public law fields, some of which succeeded in incorporating certain Islamic law rules of contracts and obligations considered viable under today's conditions, and (3) a growing number of major, topical legislation, in the form of comprehensive statutes in such fields as arbitration, banking, copyright, environment, maritime, social security, taxation, and so forth.

George N. Sfeir, The Place of Islamic Law in Modern Arab Legal Systems: A Brief for Researchers and Reference Librarians ${ }^{2}$

* Professor of Law, Georgetown University Law Center, LL.B., University of Jordan; LL.M., University of Bristol, UK; MA Philosophy, University of York, York, UK; S.J.D., Harvard

1. 1 Global Jurist Advances, no. 3, art. 5, at 6 (2001), at http://www.bepress. com/gj/advances/vol1/iss3/art5.

2. 28 Int'L J. Legal InFo. 117, 121 (2000) (emphasis added). 
Islamic law courses are being offered to students of Middle East area studies as well as law students in various American universities and law schools. The intention seems to be to educate them on law unique to the Islamic world. Things "Islamic" have of course attracted renewed and more dispersed interest since September 11, especially so in the case of Islamic law. For it was commonly assumed that it was some rule grounded in Islamic religious sources that the attackers saw as licensing their acts.

However something peculiarly worthy of notice is taking place in these pedagogical acts of instruction on Islamic law. The reading materials assigned to the students in these courses tend towards a particular construction of "Islamic law" that ultimately produces what I would describe a "fantasy effect." The fantasy is to the effect that Islamic law is a foundational category for anyone attempting to understand law in the Islamic world. Both the diachronic narrative of Islamic law's emergence and development and the synchronic interrelationship of the various contemporary legal phenomena in the Islamic world as constructed in these readings produce this "fantasy effect." Its modus operandi is a rhetorical slippage given effect to by the readings that gradually and almost imperceptibly substitutes "Islamic Law" for "Law in the Islamic countries."

The consequence? The European legal transplant in the Islamic world is never seriously explored or theorized in these materials. If referred to, it is either in its moment of arrival as a foreign import, or in its moment of fantasized departure as a thing to be displaced and replaced with something more authentic: "Islamic law." Its absence from the materials as the positive law of the Islamic world, that informs its codes, treatises, law reports, legal institutions, legal curricula in law schools is striking. This produces the paradoxical phenomenon that whereas in most other regions, scholars are typically invited to pay attention to law outside of positive law, in the Islamic world one has to do the opposite: call attention to law "in the books, in the classroom, and in the courts."

The instructor might claim that because this is a course on Islamic law, it is that which needs to be at the center of the readings and not the legal transplant. The latter needs a different course with a different title and a different discursive emphasis. But no such course seems to be forthcoming anywhere. More importantly though, a course on Islamic law can be taught that does not exaggerate the power of Islamic law to signify legal practices in the contemporary Islamic world. This course would mark the moment of historic interruption of the Islamic legal system and its loss of place for the transplant. The course would then proceed to discuss and explore with earnest interest the transplant: its nature, its rules, its operative logic, its mode of reasoning, the theory embedded in it. . . etc. 
The relationship between law and law in these course materials is thus reversed. Instead of treating the transplant as the way to understand the contemporary Islamic law as it exists as trace, the medieval Islamic legal is used to understand the contemporary legal transplant as if the latter were a mere itch on what is otherwise a Muslim body. In other words, the Islamic law instructor in the US treats Islamic law as some kind of a natural law the dictates of which declare positive law in the Islamic world as a wrong and misplaced derivation. This being the case, the latter should be ignored or forgotten through pedagogical neglect.

Thus courses on law in the Islamic world taught in the US bear almost no relationship to courses on law taught in the Islamic world itself. They certainly bear no relationship to $m y$ own legal education at the Faculty of Law in Jordan University. To graduate with a law degree, I was instructed on the Civil Code, the Criminal Code, the Commercial Code, Corporation Law, Civil and Criminal Procedure, Evidence. . .. etc., all codes designed to mimic, repeat and copy European codes. My education on Islamic law was limited to three courses which I had to take in a different school called The Department of Shar: $\mathrm{a}^{3}$ and included a course on Marriage and Divorce, one on Inheritance and Wills, and one on Islamic Jurisprudence. Nine credits on Islamic law for the four years I was studying law in an Islamic country!

A similar idea manifests itself in the writings of Islamic law scholars in the US.

In an odd reversal in which history speaks as present, the Islamic law scholar typically indulges all of us in an elaborate discussion of, say, the medieval "sunni legal thought" when the topic of rights and constitutionalism, twin concepts of Western post-enlightenment, is raised, ${ }^{4}$ as if contemporary constitutions of the Islamic world, constructed out of such post-enlightenment ideas, are of no relevance whatsoever. Similarly, another scholar "tries" Osama Bin Ladin according to medieval Islamic criminal rules, ${ }^{5}$ as if this were a law to which contemporary Muslims relate, or are even aware of, when they have adjudicated their criminal cases for over a century

3. In order for me to attend classes at the Department of Sharia at the University of Jordan, I had to "modify" my secular clothing by wearing a loose scarf on my head and get used to sitting with the other women in the class in the back rows while men "manned" the front rows. I also had to get used to the fact that the Sharia professors took attendance by calling the men with their first names and calling women by assigning them numbers! As soon as I ventured out of the Sharia building, I took off the scarf and happily walked back to my law school, where such activities did not take place!

4. Khaled Abou El Fadl, Constitutionalism and the Islamic Sunni Legacy, 1 UCLA J. IsLAMIC \& NEAR E.L. 67 (2001).

5. Frank E. Vogel, The Trial of Terrorists under Classical Islamic Law, 43 HaRv. INT'L L.J. 53 (2002). 
now in courts that are enactments of twentieth century European criminal jurisprudence. A third waxes eloquent on Islamic law's position on adultery, stoning and lashing, in a recent conference on women and Islamic law, as if such punishments have not been banished from the majority of criminal codes in the Islamic world for over a century now. ${ }^{6}$

It is not only Islamic law scholars and instructors who are committed to this "supremacy of Islamic law" approach. Comparatists do too. While traditionally preoccupied with learning about the nature of the legal transplant and the various lives the transplant acquires in different national contexts, at least within the American and European contexts, comparatists seem least interested in pursuing such an approach in the context of the Islamic world. As if sworn to its exoticism and ultimate difference, these scholars are more likely to search for Islamic law when they look at Islamic countries, only to, lo and behold, find it, typically in family law rules (Donald L. Horowitz), ${ }^{7}$ and when in search of a legal family to adopt law in the Islamic world, they readily give the "child" to the tender and warm embrace of "Muslim law" (René David) 8 or to "traditional law" (Ugo Mattei) ${ }^{9}$

The combination of presence (of Islamic law) and absence (of legal transplant) in the course materials assigned by Islamic law instructors, the scholarship on law in the Islamic world by Islamic law scholars as well as by Comparatists, betrays an ideological project. I would describe it as an identitarian one with an underlying teleological notion of history. By identitarian I mean the positing of a common identity shared by all "Muslims" based on their religio/legal beliefs, a project that to my mind recalls what I called earlier the "fantasy effect." "[F]antasy is the means by which real relations of identity between past and present are discovered and/or forged." 10 In this instance what is being "fantasized" through the assigned materials and the scholarship is the identity between Muslims in their past and Muslims in their present, as well as the identity between Muslims' relationship to their law in the past and their relationship to their law in the present. ${ }^{11}$

6. Kecia Ali, Sex, Virginity, and Honor in Islamic Law (2004) (unpublished paper presented at the conference Islam and the Law: The Question of Sexism, held at the University of Texas in Austin, Texas).

7. Donald L. Horowitz, The Qur'an and the Common Law: Islamic Law Reform and the Theory of Legal Change, 42 AM. J. Comp. L. 543 (1994).

8. Rent David \& John E.C. Brierley, Major Legal Systems in the World TODAY 482 (3d ed. 1985).

9. Ugo Mattei, Three Patterns of Law: Taxonomy and Change in the World's Legal Systems, 45 Ам. J. Comp. L. 5 (1997).

10. Joan W. Scott, Fantasy Echo: History and the Construction of Identity, 27 CRITICAL INQUiRy 284, 287 (2001).

11. Or to borrow again Joan Scott's words: "commonality among [Muslims] does not preexist its invocation but rather . . . it is secured by fantasies that enable them to 
This ideological project has an underlying teleological notion of history because it assumes that the "spirit" of Islamic law marches through history unencumbered by the world's contingencies (in this case the legal transplant). The latter might sever the relationship between Muslims-in-the-world with the spirit of their law, but this is only momentary and is destined to end. The spirit, ultimately, will be joined with its believers because the contingencies of history are inconsequential for this pre-ordained relation between believer and idea. ${ }^{12}$ Short of this moment of re-joining with the spirit, Muslims are destined to feel the bite of existential alienation. ...

Or so the fantasy goes. ...

\section{Islamic Law and Muslim Identity: Fantastical Groundings}

In one of the most succinct attempts at weaving an identitarian narrative around Muslims and Islamic law, the Islamic law scholar Wael Hallaq ${ }^{13}$ contends that for us to understand the events of September 11, it is important that we must first appreciate:

[T] he indelible connection that Muslims feel with God, a tie that the Christian West for the most part severed long ago. The idea of giving to Caesar what is Caesar's and to God what is God's does not wash in the Muslim world-view, for Caesar is only a man, and men, being equal, cannot command obedience to each other. Obedience therefore must be to a supreme entity, one that is eternal, omnipotent, and omniscient. If modernity has effected profound changes in Islamic culture (and no doubt it has), it has failed in the most important respect, namely, to alter or sever this tie with the divine. ${ }^{14}$

For Hallaq, it is the "indelible" connection to God that makes one a "Muslim," a connection that seems resistant to forces of history, including the most stubborn one witnessed thus far the world over: modernity. For whereas the Christian West has severed this connection long ago, Muslims find this connection un-severable. Accordingly, it seems redundant to describe a Muslim "religious" since what makes

transcend history and difference." Id. at 288 (note that I've substituted the word "Muslims" for that of "women").

12. This notion of history that I describe is associated with religious notions of history generally shared by Judaism, Christianity and Islam. For an explanation, see Graham Nicholson, The Locus of Meaning in the Text of History, 1 Access: HISTORY 19, 19-20 (1997), at http://www.uq.edu.au/access_history/one-one/meaning.pdf.

13. Wael Hallaq teaches Islamic law at the University of McGill in Canada. I include him in this article because of his deep influence on Islamic law scholarship in the United States. The various books he has published in which he conducts a historical investigation of Islamic law and Islamic legal theory have gained him a highly reputable and influential status in U.S. academia.

14. Wael B. Hallaq, "Muslim Rage" and Islamic Law, 54 Hastings L.J. 1705, 1706 (2003) (emphasis added). 
one a Muslim in the first place is to have an unsevered, (indeed, unseverable) connection with God by definition. To be a Muslim is to be of the faithful.

Having first asked the readers to appreciate Muslims' "indelible connection to God," the next thing Hallaq asks them to do is appreciate the Muslims indelible connection to God's law presented as necessarily flowing from the first connection:

It would in no way be an exaggeration to argue that law was the defining characteristic of Muslim societies and civilizations throughout the centuries, and in every corner of the Islamic world, ranging from Indonesia and Malaysia to Algeria and Morocco. As Joseph Schacht, the distinguished father of Islamic legal studies in the West, put it some forty years ago, "Islamic law is the epitome of Islamic thought, the most typical manifestation of the Islamic way of life, the core and kernel of Islam itself. . . . [T] lims, Arabic literature, and the Arabic and Islamic disciplines of learning are deeply imbued with the ideas of Islamic law; it is impossible to understand Islam without understanding Islamic law." . . . One may even add that law defined not only the Muslim way of life, but also the entire culture and psyche of Muslims throughout fourteen centuries. Islamic law governed the Muslim's way of life in literally every detail, from political government to the sale of real property, from hunting to the etiquette of dining, from sexual relations to worship and prayer. It determined how Muslims conducted themselves in society and in their families; how they designed and ordered their cities and towns; and, in short, how they viewed themselves and the world around them. If Islamic civilization, culture, or state ever constituted a regime of any kind, it was one of nomocracy. There has never been a culture in human society so legally oriented as Islam. ${ }^{15}$

Where did this law that was "the warp and woof" of Muslims' lives in pre-modern times come from? It was derived by medieval jurists committed to reading the words of God in his holy text through a concisely formulated "hermeneutics." 16 These jurists were educated in

15. Id. at 1707 (emphasis added).

16. The Muslim court applied what we may call "jurists' law," an expression bearing much significance. Islamic law is properly defined as jurists' law because it is a product of the jurist's hermeneutical labors, based, as it were, on the revealed texts and the methods of interpretation that were seen to derive from these very sources. The Quran stood supreme as an authoritative legal text, but the major bulk of the law derived from the Sunna of the Prophet, those utterances and deeds attributed to the founder of Islam. Juristic consensus and the inferential method known as qiyas provided the mechanisms for elaborating, in terms of legal reasoning, the raw subject matter of the revealed texts. Without qiyas and the entire system of legal hermeneu- 
institutions that were autonomous of the rulers' influence and they interpreted the holy texts independent of rulers' interests. Their authority as interpreters of God's law was such that they were able to force even rulers to submit to God's law. In the olden times, according to Hallaq, jurists were the gatekeepers of civil society, preserving its autonomy, defending it from the tyranny of the state as they spoke God's law to ruler's political power. ${ }^{17}$

Then, according to Hallaq, something awful and tragic happened in the nineteenth century. At the instigation of colonial powers, the nation state was established in the Islamic world and with it the abandonment of Islamic law and the adoption of the European legal transplant. ${ }^{18}$ The tragedy for the Islamic world was threefold: first, law was secularized:

tics developed by the jurists, the revealed texts would remain empty of legal significance, for it was this hermeneutic that brought out their legal import. In other words, God did not reveal a law proper but only textual signs or textual indications that required the intervention of the human rational faculty in order to bring out into a human reality what was seen as a sacred law. Thus, if God revealed the basic building blocks of the law, it was the jurists who built the House of Shari'a.

17. As Hallaq notes:

Politics was subsidiary to law and entirely subservient to it. This is a fact of paramount importance, dictating much of what happened between the rise of Muhammad and the early nineteenth century. The Caliph and Sultan saw themselves and were seen by all others as subject to the holy law of God. And sure enough, notwithstanding the occasional violation, both rulers and their agents took this divine superiority for granted and as a rule conducted themselves in accordance with its dictates. If there is one inalienable feature of the Muslim body politic and legal culture it is the prevalence of the rule of law, with the political sovereign accepting without challenge the supreme authority of the divine law and hence that of the jurists and judges-custodians of the law and its interpreters as well as the civic leaders of the Muslim communities wherever they were present. No ruler or political might could challenge the divine law and its spokesmen. The rich, the powerful, and the poor, from sultan to pauper, all stood as equals in the presence of the humble, informal Muslim court to receive judgment. There were no special rules for the mighty, and none could question their eternal submission to the law of God. The Law was deemed to stand above anything human.

It is this recognition on the part of the state and its functionaries that has preserved the distinction between worldly power and the province of the law. And it is this recognition that rendered the law so remarkably independent throughout twelve centuries of Islamic history. The state's legal power was accordingly limited to the appointment and dismissal of judges, and no doubt the state used this prerogative to exercise as much influence as it could muster. But the state had also accepted the fact that, once the judge was appointed, it could do nothing but bow to the Law as applied by the court. Judicial independence and the rule of law no doubt represented two of the most striking features of traditional Islamic cultures.

Hallaq, supra note 14, at 1708 .

18. Hallaq states:

By the early eighteenth century, the Ottoman Empire had ceased to threaten the gates of Vienna and had begun a process of decline, while European states experienced a simultaneous technological and economic advance. This rise ushered in a new relationship between the Islamic East and Europe, which embarked on a policy of colonization aimed at its immediate Muslim neighbors as well as the Muslim kingdoms and sultanates in far away lands. 
No longer could the traditional jurists rely on their hermeneutical methods to determine what the law was; the new order had severed the organic link between the divine texts and the positive legal stipulations deriving therefrom. The mechanism of interpretation, the backbone of Islamic law and the only link between the divine and the human, ceased to operate. ${ }^{19}$

And second, through secularization, especially that of law, Muslims experienced alienation:

The century between the 1870 s and 1970s tells a story of colossal alienation whereby Muslims were systematically exposed to a process of deprivation, first of their religious values and second of their native, age-old culture. And let there be no doubt that the decimation of their traditional law is largely responsible for both forms of alienation and deprivation. In fact, there is no other way of explaining the recent rise of the Islamist and fundamentalist movements throughout the Muslim world. ${ }^{20}$ This is undeniable. But at deeper psychological and cultural levels, the alienation stems from a severe disconnection with God; a connection that they have come to experience upon their encounter with the West, with modernity and its hegemony. ${ }^{21}$

And third, secularization through codification led to the tyranny of the contemporary Islamic nation state:

Having codified the law on the basis of Western legal models, and having virtually decimated the infrastructure of the traditional legal profession, the nation-state jettisoned Islamic law altogether and reigned supreme as the unchallenged center of legal and political power. ... a new political

The British, French, Spaniards, Portuguese, and Dutch, among others, conquered massive territories and exercised direct and indirect colonial control over them. One of the last to fall into disarray was the Ottoman Empire, most of whose possessions, save for modern day Turkey, were divided in 1916 among the British and the French in what is known as the Sykes-Picot Agreement. With this near-total conquest, the Muslim world, except such (then) impoverished regions as Saudi Arabia, faced an unprecedented wave not only of military and economic colonization but, more importantly, the modernizing effects of Europe. But even before World War I, the Ottoman Empire had been forced into a program of political and administrative restructuring whereby the initial steps toward government centralization were affected. This restructuring aimed at, and resulted in, the formation of what was to become the nation-state, an entity alien to the indigenous cultures of Muslim lands. It is in this newly emerging phenomenon that one must seek an explanation for the ultimate demise of traditional law and legal institutions.

Id. at 1711-12.

19. Id. at 1713 (emphasis added).

20. Id. at 1715 (emphasis added).

21. Id. at 1714 . 
order was allowed to emerge without the benefit of the traditional legal structures that had systemically controlled the access by political authority to real wealth (mostly concentrated in civil society but administered by the traditional legal profession) as well as to legal and absolute political power. In other words, there no longer was an independent legal system that could restrain the powers of the new autocracies. ${ }^{22}$

And why would codification lead to tyranny? Why hasn't the separation between God's law and sultan's power not been replaced by the separation between "code" and political power, otherwise known in the modern Western state as "separation of executive, legislative and judicial powers"? Hallaq has this to say:

Codification is not an inherently neutral form of law-making, nor is it an innocent tool of legal practice, devoid of political or other goals. It is in fact a deliberate choice in the exercise of political and legal power, a means by which a conscious restriction is placed upon the interpretive freedom of jurists, judges and lawyers. ${ }^{23}$

22. Id. at 1713-14.

23. Id. at 1712-13 (emphasis added). It is very hard to take Hallaq's narrative of the "tragedy of the Muslims" seriously. To disbelieve the tragedy narrative however is not to deny the brutal and destabilizing impact of colonialism on Islamic societies. When it comes to law, it seems much more plausible to argue that in those instances in which law was put to use to the service of the colonial power or its client native ruling class, it was the content of the rules rather than (the loss of) its cultural source of origin that had a destabilizing effect on Muslims. To confuse the law's distributive impact with its cultural source is to assume a) that Muslims' sense of alienation, rage, and discontent results only from the absence of the Godly source of the rules and not from the impact of those rules on their lives (!), that all law that was claimed to be God's law was experienced as a "good" by Muslims; and b) that God's law is more immediately knowable than secular law and is therefore unique in its immunity from multiple and ideologically driven interpretations. The latter would be an odd claim to make since Hallaq more than anybody else is aware of the range of interpretations of God's law that existed in medieval times leaving little doubt that while God might be clear about His own intentions, we are only aware of them through human interpreters and humans are not immune from biases and preferences of their own. The paradox in Hallaq's position stems from his uncritical attitude towards Islamic law as religious law. He suggests that unlike codified law, which is openly ideological according to him, God's law rises above human and state preoccupations and biases. $\mathrm{He}$ implies that the Muslim jurists' hermeneutics exemplified by analogy has somehow made it possible to have access to this supra-ideological will. Hallaq seems unaware that what he says about God's law only repeats what classical legal thinkers in the US said about law in the nineteenth century. Instead of jurists, in whom Hallaq places his trusting faith, the CLTs placed theirs in judges and their deductive and analogical hermeneutics which they thought guaranteed the objectivity and neutrality of the law they made. As we know, such claims were more or less put to rest by the devastating attacks of the legal realists in the early twentieth century and the critical legal thinkers later on. Even more importantly, Hallaq fails to mention similar attacks made on analogy and its claim to objectivity in the history of Islamic law itself (Shatibi, Ibn Rida, etc.). 
So according to Hallaq, first there was God who begot the law who begot the Muslims. Then colonialism, the nation state and the legal transplant happened. As a result, Muslims found themselves suffering a lack they have since then sought to bridge, one that is created by the absence of the law that mediated their relationship to a God in whom they never lost faith. It is this lack, gap, desire, call it what you will, that is at the heart of Muslim's contemporary sense of alienation. And yet in order for the alienation thesis "to stick," one has to believe that the loss of the law has done nothing but create a gap between Muslims and their God, that the category "Muslims" (and for that matter "God") has retained its internal coherence despite the loss. For there to be a longing for a reunion with the law lost there has to be a Muslim self yearning, an idealized supra historical self that defies the forces of history, that stays the same even though it had lost its law, that even though it is the law that defines what a Muslim is, the Muslim has managed to survive and supercede "his" foundational law. ...

Hallaq's narrative however quickly breaks down when Hallaq finds himself forced to contend with real Muslims, and when he does, he is unhappy with what he sees. The real Muslim, the Muslim-inthe-world, turns out to be only a pale shadow of the idealized one that Hallaq warmly embraced in his imagination. In his account of the contemporary "Muslim discourses" on how to deal with the "predicament" of loss-of-law-based alienation, here is how Hallaq describes the discourse that the majority of Muslims subscribe to according to his own admission:

This camp, which represents the majority of ordinary Muslims as well as the surviving but marginalized pockets of the educated, religio-legal class, has not shown adequate awareness either of the structural and fundamental effects of modernity or of their own past. To the members of this camp, modernity is an indistinct phenomenon and their past is a myopically perceived image, justifying anything that the present happens to offer. An index of their perceptions is their insistence on religion as a guide to life and an incoherent acceptance of modern ideas and institutions. ${ }^{24}$

It is hard to ignore the unflattering terms with which Hallaq describes the "majority of ordinary Muslims." They lack "awareness," they have a "myopically perceived image" of their past, and suffer from an "incoherent acceptance of modern ideas." What is it that the majority of Muslims have done to earn Hallaq's profound disappointment and discontent? They refuse to be alienated from their present and refuse to long for an idealized past: they have "not shown ade-

24. Hallaq, supra note14, at 1716 (emphasis added). 
quate awareness either of the structural and fundamental effects of modernity or of their own past." On the contrary, they have the tendency to "[justify] anything that the present happens to offer." Given Hallaq's harshness on ordinary Muslims, one is left with the conclusion that the real tragedy is not that of Muslim's alienation and longing for their law, but of Hallaq's own romance with the idealized Muslim. Descend from the pedestal down to earth, and the loved one (the Muslim) turns out to be no more than a hybrid of things, a "freak" who rejects simple dichotomies and simply patches and collages her various identities as she tries to survive her national postcolonial reality. Ah! The aches of lost loves.

Wael Hallaq is unusual in the fact that he recognizes the deep and interrupting influence the legal transplant has had in the Islamic world. I will argue below that when it comes to Islamic law instruction in the classroom, most instructors tend to ignore the transplant altogether or to mention it only cursorily. However, Hallaq shares with the rest of the instructors a desire for a return of Muslim to law.

\section{Rhetorical Strategies Designed to Produce the Fantasy Effect In Course Descriptions and Syllabi Relating TO ISLAMIC LAW}

In this section I discuss the syllabus/course descriptions of three Islamic law scholars: Frank Vogel of the Harvard Law School, Sherman Jackson of the University of Michigan and its law school, and Khaled Abou El Fadl of the UCLA School of Law. I use their instructional literature, at least what I was able to get hold of, because of their status in the field as some of the most venerable scholars of Islamic law and because of the status of the law schools in which they teach. It is my belief that they have, because of these twin factors, inordinate influence on how the field is described and taught.

In a course on Islamic law offered in the aftermath of September 11 entitled, "Contemporary Islamic Legal Thought: Law, State, and World Order,"25 the syllabus begins in the first week with "an orientation to the course" through introducing the students to "early Islamic legal history covering the prophetic and early succeeding generations." 26 The syllabus proceeds to trace Islamic law from this foundational era to the following one, namely that of the classical era (9-13 AD). In this part of the syllabus one is introduced to the mode of

25. The instructor of this course is Frank Vogel of Harvard Law School. The course was most recently offered in Spring 2003. The Spring 2003 syllabus is available at http://www.law.harvard.edu/faculty/vogel/courses/islamic/courses/ (hereinafter "Vogel Syllabus").

26. Early Islamic legal history has its textual basis in "the quran and the sunna of the prophet." 
legal scholarship characteristic of the schools of law of the classical period, as well as the main legal operators/ producers of legal rules in these schools (muftis, jurists). The third week revolves around the law of "worldly authority" that centers the discussion around the notion of the caliphate in medieval times. Discussion of worldly authority takes the student to the Ottoman era (16-20th century). We now come to the modern period marked by the transplantation of European Codes. ${ }^{27}$ But the syllabus pays scant attention to them. The week designed to discuss the transplant merely surveys the history of transplantation in the various parts of the Islamic world using Liebesny. ${ }^{28}$ Having "paid homage" in a polite and cursory way to the "Western styled" modern legal systems barely noting their occurrence, the syllabus marches forward to the "next thing" as if the "Western-styled" was a trifle and ordinary event:

The dismantling of Islamic legal systems from 1800 onward in favor of new Western-styled systems. In most countries the jurisdiction of Islamic law and courts is reduced to the laws of the family. Emergence of other models for the Islamic constitution including that of the modern nation state based on popular sovereignty. Survey of now extant Islamic legal and constitutional models and of how Islamic law is now applied worldwide. ${ }^{29}$

The paragraph above is making an odd claim to my mind. In the first half of the paragraph it informs the student that the Islamic legal system has been dismantled and that nothing of the medieval system has survived except the "laws of the family." However, in the second half, it proceeds to describe the emergence of "the Islamic constitution" that is based on "popular sovereignty." What is odd about this claim is that legal institutions such as "popular sovereignty" and the "constitution" are very modern concepts, the cultural products of the post-enlightenment liberal West. Their emergence in the Islamic world could only be attributed to the transplant and therefore attach-

27. The modern period is characterized by a) colonization of the Islamic world by France and Britain primarily; and $b$ ) modernization projects initiated by local elites to preempt colonial pressure but also following colonization. When it comes to law, this era is marked by the importation of legal transplants from Europe (beginning with the introduction of criminal, commercial and procedural codes, codification of certain Islamic rules on private law and ending with the introduction of national civil codes). So much so that the bulk of extant legal texts in the countries that have Islamic majorities today including the courts that administer those texts, distributed along multiple appellate levels and manned by secularly trained judges as the main operators of this system. Such imported legal institutions (texts, interpreters and operators) have seriously displaced the preceding legal system discussed in Vogel's syllabus thus far.

28. Herbert J. Liebesny, The Law of the Near \& Middle East: Readings, Cases and Materials (1975).

29. Vogel Syllabus, supra note 25 , at Feb. 11, 2003. Italics in the quote are mine, meant to highlight the places in which the ambiguity of the property "Islamic" is being made use of by the author of the text. 
ing the word "Islamic" to them could only mean that the signification of the word "Islamic" has shifted from the first half of the paragraph to the second. In the first half, "Islamic" referred to law that is foundationally Islamic, i.e., derived from Islamic religious sources by Muslims trying earnestly to develop law that is attributable to texts that they treat as peculiar to them as Muslims. In the second half, the word "Islamic" seems to now refer to a "law/constitution" adopted by Muslims from elsewhere as the textual foundations of this law seem to, as historical fact, lie elsewhere. In other words, what is Islamic about law in the first instance is its textual source, and what is Islamic about law in the second instance is the identity of its importers. Indeed, the last sentence of the paragraph "Survey of now extant Islamic legal and constitutional models and of how Islamic law is now applied worldwide" proceeds to use both meanings of the word "Islamic" to indicate the latter meaning in the first usage (identity of the user of the legal text) and the former meaning in the second (identity of the text itself).

The slippage from one meaning to the other is very subtle and allows the author to treat the history of Islamic law as continuous with and the same as history of law in the Islamic countries. This in turn explains how "Islamic law" in this approach can be described as dead ("dismantled legal system") and not dead ("emergence of the Islamic constitution") at the same time. It also allows the author to "smooth over" the radical interruption in the "identity of the legal text" that occurred as a result of the transplant. For having registered the occurrence of the transplant earlier on in the paragraph "The dismantling of Islamic legal systems from 1800 onward in favor of new Western- styled systems" in a "confessional" mode, the instructor proceeds to "deny" it through transferring the identity Islamic from text to importer, therefore stripping the imported text from its threateningly "interrupting" quality.

However, if one proceeds to read the second paragraph of the syllabus one notes that attributing the word "Islamic" to "constitution" in no way leads to a serious discussion of the transplant now called Islamic. One would think that describing the constitution as Islamic might encourage the instructor to discuss it in a mode of "embrace" now that it's dangerous imported quality had been tamed through appropriation. No such thing happens however. Witness the next thing that the instructor asks the students to do:

Analyze: What is needed from an Islamic legal theory today, not only in respect to determining legal rules or outcomes (usul al-fiqh) ${ }^{30}$ but also with respect to shaping the

30. Usul al-fiqh: refers to the legal theory first innovated by the famous Muslim jurist Muhammad Ibn Idrîs al-Shâfi'î in the ninth century. The era of $U s u l$, which spanned the early centuries of Islam, was one in which the schools of law innovated 
legal institutions and legal systems that uphold law generally, including importantly constitutional structures (usul al. hukm)?31 What traits would a successful contemporary Islamic legal theory have?32

On the contrary, the constitution is picked as "Islamic" only to be dropped in the next sentence in a complex act of disavowal. For it turns out that our next task for this constitution is to revert it back to the old sense of being "Islamic," i.e., to work at reconstructing it so that it loses its imported quality and becomes textually Islamic, not merely Islamic by virtue of being embraced by Muslims "shaping the legal institutions and legal systems that uphold law generally, including importantly constitutional structures (usul al-hukm)?" How do we do that? Well, through a skillful use of "usul al-fiqh," i.e., back to the textually Islamic.

So if one were to map the rhetorical strategy of the syllabus that allows the instructor to ignore the transformative impact of the transplant on law in the Islamic world, one finds that it is based first on, embrace of the transplant by attributing to it the quality "Islamic" only to disavow it by calling for "reconstructing" by what is truly "Islamic."

The dizzying back and forth usage of the word "Islamic" in course descriptions is quite common. For instance, in a course description of an "Introduction to Islamic Law" seminar, the instructor" 33 writes:

Islamic law is one of the oldest and most significant systems of law in the contemporary age. We will study the history, theory and the role Islamic law in the contemporary age. . . The course will be divided into two main parts: the first will deal with Islamic law in the classical context while the second will examine the role of Islamic law in the contemporary age. We will begin by considering the question of "Why study Islamic law?" We will then move on to the history and theory of the Islamic legal system with a special emphasis on the development of the various schools of thought in Islamic law. In the second half of the course we will survey Islamic commercial, criminal and family laws and their influence on the modern age. Furthermore, we will examine Islamic public in-

rules inspired directly by the sources of the religion, i.e. the Qur'an and Hadith. This was done through ijtihad, the religious and legal project of coming up with new rules of law directly inspired by the sources of the religion, or exerting one's effort to discover God's law on a particular matter

31. Theory of Governance

32. Vogel Syllabus, supra note 25, at Feb. 13, 2003 (emphasis added).

33. The instructor of this course is Khaled Abou El Fadl of the UCLA School of Law. The course offered at the UCLA School of Law is numbered Law 335, and its description is available at http://www.law.ucla.edu/home/index.asp?page $=211$ (hereinafter "El Fadl Course Description"). 
ternational law, human rights and Islamic law and the Muslim minority in the United States. ${ }^{34}$

The course description above is another example of the way the double use of the word "Islamic" functions as a complex maneuver designed to DENY the transplant through a double act of appropriation and rejection. The instructor uses the word "Islamic" to mean "textually Islamic" in "Islamic law in the classical context." However, the use of the word "Islamic" in the second paragraph is much more complex. What is interesting is attaching the word "Islamic" to "commercial, criminal and family laws." Whereas Muslims produced a great deal of doctrine in those areas of the law, the division of the fields into "commercial, criminal, and family" was unknown to them. Muslims have come to know these divisions of doctrinal fields through the transplant. One effect of the use of the word "Islamic" then in this context is a projection back to the past in which medieval doctrine is now seen as divided into doctrinal fields similar to those of the modern transplant. To my mind the implicit idea in this kind of textual organization is to suggest, that medieval Islamic law is comparable to the modern transplant. Feeling compelled to re-present the Islamic law of medieval times in "transplant" terms attests to the power of the transplant. However, this power is quickly resisted by the instructor through relegating it to a modest place: it's already "corrupted" by the medieval Islamic, "their influence on the modern age." While it is true that the modern transplant in the Islamic world has incorporated some rules developed in medieval times, what is interesting in this context is that the course description fits this indisputable "fact" into its identitarian project. To preserve the smooth unfolding of the identity "Islamic" of the law in the narrative of the text, the transplant becomes a thing to be "influenced" as the spirit of Islamic law marches forward transforming all things un-Islamic in its path. The structure of the text would look very different if the author chose to admit a discontinuity in the identity of the law as a result of the transplant, of the identity of Muslims as a result of colonialism/post-colonialism. In this case, the transplant is centered as the "new age" of law, heralding a new dawn of complex identity, in which "Islamic" is only one of them. The "center" and the "periphery" of the text, is in this case reversed.

Another way of making the same point: the discursive strategy of the course description seems to be: rather than recognize the legal transplant for what it was as an "interruption" in legal text, institution, discourse, and interpretation, initiating a radically new colonial/ post-colonial legal history, it is instead treated as an occurrence to Islamic law within an overall movement of the unfolding of Islamic

34. El Fadl Course Description, supra note 33. Italics are mine designed to point out the place where I believe the "rhetorical" slippage takes place. 
history. That is the "Islamic legal" is not displaced by the transplant, it merely changes into "it" for the moment, doomed to feel uncomfortable in this new and unnatural incarnation which is why it (the Islamic legal) is bound to shed it (the transplant), after adopting some of its features, and return to its originary self.

In another course description the instructor ${ }^{35}$ presents his course in the following way:

This course will introduce students to classical Islamic legal theory and some applications of positive law in the Sunni tradition. After a brief review of the seminal controversies that defined the "formative period," and the development of Islamic legal theory, we will examine the interpretive modus operandi of the full-blown schools of law in the "post-formative" era. This will include an examination of such key issues as ijtihad versus taqlid, the madhhab (or school of law), the legal responsum (fatwa), legal [eclecticism], and the issue of legal change, stasis and borrowing. This will be carried out via a general overview of a number of areas of positive law, e.g., marriage, divorce, abortion, child custody and legal procedure. The course will conclude with a look at developments in Islamic legal thinking in modern times, including an examination of some legal responsa (in translation) to some important modern controversies and a few samples of jurisprudential writings of Muslim scholars in the East and West.

The description above doesn't even attempt to refer to the transplant either directly or metonymically. Once the students have finished exploring the medieval era, including exploring such legal institutions and practices as Ijtihad, taqlid, madhhab, Fatwa (all features of the classical era), they are invited to "look at developments in Islamic legal thinking in modern times, including an examination of some legal responsa. ..." Legal Responsa (Fatwa) is a reference to legal opinions issued by religious figures in the context of private legal consultation, in which the "Mufti" is asked for his legal opinion on a hypothetical matter posed by a questioner. Ifta' was a form of legal practice that was central in the medieval era. The practice of "Ifta" (to issue Fatwa) exists today on the margins of the official legal system and represents, in my view, an instance of the way religious law has been to a large extent "privatized" since the advent of the legal transplant. While Ifta in the classical era lived in a collaborative and

35. Sherman A. Jackson, Associate Professor of Arabic and Islamic Studies, the University of Michigan, and Adjunct Professor of Law, the University of Michigan Law School. The course described is offered at the University of Michigan Law School as Islamic Law. The course description is available at http://cgi2.www.law. umich.edu/_ClassSchedule/aboutCourse.asp?crse_id=038904. 
harmonious way with other forms of legal practice especially adjudication, it has lost its central place in the modern era as adjudication acquired a state-based and code-based quality. As a result, the mufti has been transformed into a private legal consultant to a multitude of religiously driven advice seekers. The description above explores the (textually) "Islamic" in the medieval period, and pursues it in contemporary times through concentrating on one of its surviving practices. Thus continuity of the Islamic is preserved, albeit through the pursuit of a trail that becomes thinner and thinner as we approach modern times. The course doesn't seem to explore the causes for the progressively disappearing trail nor even attempt to recast Ifta, not as continuous practice of Islamic law, as it seems to do, but rather as a transformed practice that lives dialectically at the margins of a new legal system. ${ }^{36}$

36. While one organizer of a course entitled Islam and the Rule of Law offered by Stanford University recently explains that offering the course came as "a response to students and faculty groups who strongly desired a better understanding of the rule of law in Islamic societies in the aftermath of Sept. 11," another explains the problem in the following manner, "we know precious little about legal traditions in Islam." Lisa Trei, New Course to Teach 'Authoritative'-Not Authoritarian-Interpretation of Islam, STAN. REC., Jan. 8, 2003, at http://news-service.stanford.edu/news/2003/january8/islam-18.html (quoting Eric Jensen and Coit Blacker) (emphasis added). The confusion of the organizers of the course for whom understanding "the rule of law in Islamic societies" is the same as getting to know the "legal traditions in Islam" only points to the depth of the problem. When the former insists that "the interpretation of the Koran is the most important issue among the faithful . ... [e]verything else flows from this," it becomes clear that in the organizers' minds what makes a society Islamic is its "faithful," and that it is their law "flowing from the Koran" that constitutes "the rule of law in Islamic societies" that we need to "understand." Id. (quoting Eric Jensen) (emphasis added). The course is structured in the following manner. It begins with a lecture entitled "Introduction to Islam and Islamic Law: The Historical Development of Islamic Law" (offered by a historian), moves on to a lecture on "Gender and Islamic Law" (offered by a historian), third, a lecture entitled "Interpretation and Authority in Islamic Law" (offered by a historian), followed by "Islam and the Rules of War" (offered by a law professor), comes back to gender again "Women's Rights, Religion and the State in Islam: Muslim Women's Civil Society Organizations and Policy Advocacy" (offered by a law professor), followed by "Rule of Law: Practitioners' Session (offered by development specialists) and ends with a lecture on "Economic Development and Islamic Law" (offered by an economist). While historians are asked to speak of history, development specialists of "programs promoting rule of law in the Arab world, economists of "classic economic concepts in Islamic jurisprudence," the lawyers are asked to talk of gender and war under Islamic law. Id.

In a nutshell, according to this course, Islamic law is a historic religious text used to oppress women, wage war on the West, but is hopefully open to reform through new forms of "interpretation and authority," "civil society advocacy," rule of law programs by development agencies, and last but not least, modernization of its economic and financial policies. In other words, rule of law reform projects are represented as a "gift" offered to those with a hang up on some olden religious text with its olden premodern rules. There is no modern state law in place that mediates between the two, no modern legislated law, no modern court, no code, no internationally signed treaties, no constitutions, nothing, only the faithful and their text. In order to appreciate the nature of this fantasized object called "Islamic law" and offered us to understand in the wake of September 11, let us imagine what a course on "Islamic law" would look like if the contemporary hybridity of Islamic law were taken into account. I imagine that a course like that would begin with "The Historical Development of Islamic Law" 
In this section I have attempted to describe the strategies pursued by Islamic law scholars in their pedagogy on Islamic law. I have identified two such strategies: first, the instructor starts the course with medieval law, and once history takes the students to the modern legal transplant, the instructors doesn't spend much time on it, rather, in an act that wishes the transplant away, he proceeds by inviting the students to reconstruct the transplant, ie, see it through medieval Islamic eyes. The project of reconstruction the students are invited to engage into has of course strong liberal undertones. In the second strategy the instructor starts with medieval law and when he deals with the contemporary period he pursues a thin trail of Islamic law that has survived in modern times (such as Ifta, or family law, or Islamic rules on contract) while ignoring the contemporary law in which these Islamic legal practices have become a part of. This produces the effect that Islamic law has continued its path from the medieval to the modern, everywhere. . .

\section{ISLAMIC LAW SCHOLARSHIP IN THE US}

Islamic law scholars in the US are for the most part of a liberal conviction. What the Muslim and non-Muslim among them have in common is the project of dispelling stereotypes about Islam and Islamic law in the US, especially among non-Muslims. Those among them who are Muslim ${ }^{37}$ acquire their identity as "liberal Muslim" through an act of triple differentiation: first from the conservative religious Muslim (whether of the traditionalist or fundamentalist stripe), second, from the secular Muslim, and third from the "orientalist" non-Muslim scholar. When it comes to the religious they are liberal (with whom they share the belief that religion is a foundational category for Muslim culture), and when it comes to the secular they are religious (with whom they may share liberalism as a com-

followed by a lecture on "Colonization, Modernization and Law in the Islamic World," followed by "A History of Codification in the Islamic World," moving on to three sessions that discuss positive rules in the Islamic world "Comparative Discussion of Rules of property (tort, rape, corporation, tax, social security, emergency) in Indonesia, Pakistan, and Egypt." This would then lead us to a discussion of "Emergent Constitutional Jurisprudence in the Islamic World: Comparing the constitutional decisions of Pakistan, Kuwait and Egypt," moving on to "Discussion of Adjudication in the Islamic World: Relationship between Lower Courts and Higher Courts," followed by "Legislation and Legislative Processes: Relationship between Executive and Legislative in the Islamic World," followed by, "Legislating the Family in the Islamic World: Secular Feminism or Reformed Islamicism". . . Once we introduce into the picture the intermediation between the "Muslim" and his religious text of the modern state in the Islamic world, identify its laws as primarily modern national products, as opposed to Islamic, the modern nation understood as a complex product of a history of European colonization and modernization by national(ist) elites, then the picture is instantly transformed. The solipsistic relationship between the Muslim and his text that the identitarian project assumes is broken. . .

37. Khaled Abou El Fadl and Aziza al-Hibri, Professor of Law at the T.C. Williams School of Law at the University of Richmond, are classic examples. 
mon faith), and when it comes to the orientalist scholar they are critics (with whom they share the belief that Islamic law is a foundational category for Muslim culture).

When it comes to the first, they pursue the tactic in their writings of "liberalizing" the believers by freeing them from the "misinterpretation" of the conservative or fundamentalist voices. Whether they are addressing an American Muslim religious student body, supervising the scholarly work of graduate students from the Islamic world, engaging themselves with the affairs of the immigrant Muslim community, or addressing a non-Muslim American audience, liberal scholars of Islamic law, see themselves (and are for the most part ${ }^{38}$ seen) as paragons of reasoned study and elaboration in a world full of religious fraudulence, passive receptivity to inherited misinterpretations, and unabashed bias. Some of those scholars have attracted the limelight in the aftermath of September 11, seen by the liberal media as the voices of "moderation" in the Muslim community, those that assure us that "Muslims" are not really very different from us (if only they understood their religion right!).

When it comes to the second, the secular Muslim, the liberal Muslim Islamic law scholar, is for the most part dismissive. His/her dismissiveness of the secular Muslim is quick, impatient, and confident, assuring their Muslim and non-Muslim audiences that secularism in the Islamic world is an import ideology from the West that has been tried and failed and has therefore been illegitimate. The rise of the religious movements in the Islamic world since the mid-seventies of the twentieth century is typically given as a sign of the ultimate unacceptability of secularism among "Muslims" as ideology. ${ }^{39}$

38. Campus Watch is an example of an organization that is critical of these liberal scholars. According to their Web site, Campus Watch is an organization that "reviews and critiques Middle East studies in North America with an aim to improving them." See Campus Watch at http://www.campus-watch.org/.

39. El Fadl, supra note 4, at 93-94:

To propose secularism as a solution, to avoid the hegemony of Shari'ah and the possibility of an abuse of power is, in my view, unacceptable. There are several reasons for this. First, given the rhetorical choice between allegiance to the Shari'ah and allegiance to Constitutionalism, most Muslims will make the understandable, equally rhetorical, decision to ally themselves to the Shari'ah. Secondly, secularism has become an unworkable and unhelpful symbolic construct. In the Muslim world, secularism has been normally associated with what is described as the Western intellectual invasion, both in the period of Colonialism and post-Colonialism. Furthermore, secularism has come to symbolize a misguided belief in the probity of rationalism and a sense of hostility to religion as a source of guidance in the public sphere.

The third consideration remembers the earlier point that, beyond the issue of symbolism, there is a considerable variation in the practice of secularism. It is entirely unclear to what extent the practice of secularism requires a separation of church and state, especially in light of the fact that there is no institutional church in Islam. Put differently, to what extent does the practice of secularism mandate the exclusion of religion from the public 
When it comes to the orientalist, the liberal Muslim, is a critic at large, outraged at the misrepresentations of Islamic law by the orientalist scholar, charging the latter with giving Islamic law short shrift, begrudging it its richness, ingenuity, capacity to evolve, and autonomous contributions to legality. In short, the liberal Islamic law scholar is a critic of the orientalist's non-recognition of Muslim legal genius. ${ }^{40}$

But it is very lonely to be a liberal Muslim Islamic law scholar. Haunted by the formalism of the conservative believer flaunting the text in his face, accusing him of giving God's word short shrift through misinterpretation, taunted by the secular Muslim's invitation to quit all this religious talk and simply "come out" as a run-ofthe-mill Western liberal, nervous about the secular historiography of Islamic law that charges Muslims of projecting back unto the prophet traditions they themselves invented, the liberal Muslim Islamic law scholar is in a real bind. Caught between being an anti-formalist in relation to the first, and a formalist in relation to the second and third, the liberal Muslim Islamic law scholar is involved in a strict balancing act that threatens to push him to one side or the other.

\section{Liberal Islamic Law Scholarship: A Tricky BaLAncing Act}

Unless the conception of government is founded around core moral values about the normative purpose of Shari'ah, and unless there is a process that limits the ability of the government to violate those core moral values, the idea of a government bound by Shari'ah remains hopelessly vague. It is quite possible for a government to faithfully implement the main technical rules of Shari'ah, but otherwise flout the rule of law. In fact, implementation of the technicalities of Shari'ah can be used as an excuse for allotting the government unrestrained legislative and executive powers. For instance, in order to guard modesty, the government could issue arbitrary laws forbidding many forms of public assembly; under the guise of protection of orthodoxy, the govern-

domain, including the exclusion of religion as a source of law? Finally, to the extent that the secular paradigm relies on a belief in the guidance-value of reason as a means for achieving utilitarian fulfillment or justice, it is founded on a conviction that is not empirically or morally verifiable. One could plausibly believe that religion is an equally valid means of knowing or discovering the means to happiness or justice.

The fact that secularism is a word laden with unhelpful connotations in the Islamic context should not blind us to the fact that the discourse of Shari'ah enables human beings to speak in God's name, and effectively empowers human agency with the voice of God.

40. Hallaq, supra note 14, at 1707 ("[A]t the heart of Muslim politics and political theory, and at the basis of their conduct and conception, there lies a significant deposit, if not a rich substrate, of law"). 
ment could pass arbitrary laws punishing creative expression; under the guise of protection of individuals from slander, the government could punish many forms of political and social criticism; and a government could imprison or execute political dissenters under the claim that they are sowing fitnah (discord and social turmoil). Arguably, all such governmental actions are Shari'ah-compliant unless there is a clear sense about the limits imposed upon the ability of the government to service even the Shari'ah. Put differently, the rules of law cannot be used as an excuse to flout the rule of law, and the state cannot be allowed to usurp the process by which Shari'ah law is determined. ${ }^{41}$

The author of the above quote is engaged in an "Islamic law" reconstructive project. His declared purpose is to mine "Sunni legal thought" for constitutional potential. ${ }^{42}$ In order to do that, the author reads medieval political and jurisprudential literature discussing "justice," "the contract of the Caliphate," "Shura" (government by consultation), "huquq Allah" (rights of God), and "huquq al-ibad" (rights of people), etc. The question for him seems to be: if we dug the Islamic medieval politico/legal mine ardently and discriminatorily enough, will we find a liberal constitution with rights, democracy, and all, waiting to be "undug"? The answer in the end is of course yes, (otherwise why do it) but with a proviso: doctrinal potential for constitutionalism is one thing, political culture is another,

As noted earlier, constitutional practice appropriates the values and intellectual heritage that prevails within a society. Although sparks of constitutional thought were definitely generated in the Islamic intellectual heritage, it would be an exaggeration to claim that constitutional values or normative orientations are a consistent part of this tradition. But it is these sparks that can be co-opted in the contemporary age, and developed into full-fledged constitutional visions with potential to contribute to constitutional practices. ${ }^{43}$

Well, who could disagree with that? Constitutionalism is good in modern times. To ensure that it sticks in a particular society, ac-

41. El Fadl, supra note 4, at 74 .

42. Id. at 68 :

Therefore, this essay will focus on potentialities-i.e., the doctrinal aspects in Sunni political thought that could legitimate, promote, or subvert the emergence of a constitutional practice in Muslim cultures. These doctrinal potentialities exist in a dormant state until they are co-opted and directed by systematic thought supported by cumulative social practices. This essay concerns itself with doctrinal potentialities or concepts constructed by the interpretive activity of Muslim scholars (primarily jurists), but will not focus on the socio-political practices in Islamic history.

43. Id. at $92-93$. 
cepted by its masses as an organizing political ideal, it's best if this idea could be projected back onto this society's historic texts. ${ }^{44}$ So why not dig hard and deep into the medieval Islamic politico/legal texts and interpret constitutionalism whenever they give you the slightest hint?

Well, the problem is twofold. First, the particular "texts" that the author chooses to do the digging into are all pre-modern Islamic:

This essay concerns itself with doctrinal potentialities or concepts constructed by the interpretive activity of Muslim scholars (primarily jurists), but will not focus on the sociopolitical practices in Islamic history. ${ }^{45}$

Of all those "Muslim jurists," or shall we say "dead brown men," whose work the author mines for constitutional "doctrinal potentialities," the youngest died circa the fourteenth century! ${ }^{46}$ It is obvious that for the author, "Islamic" is a peculiarity of a particular culture, and it derives this identity from texts written sometime before the fourteenth century.

To my mind, this begs the question: what about contemporary texts produced by contemporary Muslims on constitutional jurisprudence? What about the decisions by the Supreme Constitutional Court of Egypt? What about the modern treatises on constitutional jurisprudence that are taught in law schools all across the Islamic world? What about all these dissertations being written by graduate law students in the Islamic world reading European and America jurisprudence on constitutionalism and trying to develop a modern local version of constitutionalism in their own local cultures? What about all these types of legal reasoning developed by contemporary constitutional courts in the Islamic world in which they are addressing contemporary problems of constitutionalism? Do they all count for nothing? What is the meaning of a reconstructive act that pushes all these doctrines and texts aside and instead goes further back in time in search for Islamic constitutionalism? How are we to understand this search for the "origins"? ${ }^{47}$

44. The author begins by voicing the following cautionary note about his project: It is doubtful whether it is helpful to abstract the doctrines of constitutionalism from their remarkably diverse cultural and social contexts. Constitutionalism reflects embedded normative values that arise from evolved historical practices that are not easily transplanted outside their natural habitat. In many ways, constitutionalism must be practiced and not theorized. Therefore, one cannot help but worry that speaking of constitutionalism in Sunni Islamic thought is not only an anachronism, but also an abstraction that ultimately will yield limited insight.

Id. at 67.

45. Id. at 68 (emphasis added).

46. See footnotes of his article.

47. The author could respond to these questions by asserting that he's simply not interested in these contemporary texts but in "Sunni legacy" as the title of his article reveals. Yes, but that only begs the question: why the "Sunni legacy"?? why "legacy"? 
It seems to me that the author's reconstructive project here mimics the approach of the Islamic law instructor above. It assumes away contemporary law, jurisprudence, and legal reasoning. In other words, it assumes away the transplant (for all contemporary constitutions in the Islamic world are transplants). Why? I can only guess that the author doesn't think that these legal phenomena meet the "Islamicity test." For they are all based, aren't they, the jurisprudence, the doctrine, the mode of reasoning, on a transplanted text, one that cannot be seen as "organic" and therefore any legal infrastructure built on it, cannot be taken seriously. It's foreignness doesn't cease, the rationale seems to go, even if contemporary Muslims worked around it, on it, from it, towards it, etc.

All this leaves the impression with the uninformed reader that it is only when we look into the medieval that we can find the authentically Islamic and therefore the only (potentially) legitimate constitution in the Islamic world must be one derived from that era. For if the Islamic world has proven to be thus far "unconstitutionally" oriented, dictatorial, authoritarian, undemocratic, at least a big part of the reason must be that whatever constitutional legal infrastructure it does have is not Islamic. And therefore, the author's earnest reconstructive project. . . 48

What makes our author a liberal Muslim Islamic law scholar is that his piece, as typified by the quote that at the beginning of this section, concerns itself with the religious Muslim who advocates a Sharia based constitution and offers in response a "core-valuesabove-the-Sharia" based constitution:

Unless the conception of governance is founded around core moral values about the normative purpose of Shari'ah, and unless there is a process that limits the ability of the government to violate those core moral values, the idea of a government bound by Shari'ah remains hopelessly vague. ${ }^{49}$

His core values are identifiably liberal (individual rights, democracy, etc), the outcome of his mining-the- medieval- texts activity. His textual anti-formalism in which he refers the Muslim to "the normative purpose of Sharia" instead of its positive laws is typical of the liberal

48. The type of implicit reasoning (implicit in the reconstructive project) doesn't seem plausible to me. The appeal to "Islamicity" is typically presented as the request of the "masses." However, lack of constitutionality is never due to the rejection by the "masses" of foreign ideas implanted in their constitutions, such as individual rights, separation of powers, etc, because these doctrines obviously work for their benefit, at least on their face, but because the ruling elites refuse to make those constitutions meaningful for the masses. It is very doubtful to me, given the contemporary structure of the ruling classes in the Islamic world, that even if we come up with a more "authentically" Islamic constitution, that we will somehow be that much closer to extracting democracy from those elites.

49. El Fadl, supra note 4, at 74; see supra note 41 and accompanying text. 
religious argumentative strategy in the face of religious conservative formalism.

What makes our author a religious liberal Muslim Islamic law scholar is his dismissal of the legal activity (jurisprudence, doctrine, legislation) associated with the modern non-religious Muslim state. To recognize these legal phenomena would force the author to recognize the complexity of contemporary hybrid identity of Muslims that includes the secular and the religious and a whole spectrum in between. To recognize the hybridity would locate his reconstructive project in a particular ideological domain: a debate among a particular category of Muslims, namely, the religious ones. To recognize the ideological location of his project would turn his project from a legal constitutional reconstructive project to a religious constitutional reconstructive project.

This brings me to the second problem I have with the author's liberal religious reconstructive project, which represents the larger dilemma of those subscribing to it, namely the circular way in which he first dismisses secularism in the Islamic world as "unacceptable" only to return to it through re-interpretation of religious texts. Having dismissed secularism in the Islamic world in this manner:

To propose secularism as a solution, to avoid the hegemony of Shari'ah and the possibility of an abuse of power is, in my view, unacceptable. There are several reasons for this. First, given the rhetorical choice between allegiance to the Shari'ah and allegiance to Constitutionalism, most Muslims will make the understandable, equally rhetorical, decision to ally themselves to the Shari'ah. Secondly, secularism has become an unworkable and unhelpful symbolic construct. In the Muslim world, secularism has been normally associated with what is described as the Western intellectual invasion, both in the period of Colonialism and post-Colonialism. Furthermore, secularism has come to symbolize a misguided belief in the probity of rationalism and a sense of hostility to religion as a source of guidance in the public sphere. ${ }^{50}$

The author ends his article with the following assertion:

All laws articulated and applied in a state are thoroughly human, and should be treated as such. Consequently, any codification of Shari'ah law produces a set of laws that are thoroughly and fundamentally human. These laws are a part of Shari'ah law only to the extent that any set of human legal opinions is arguably a part of Shari'ah. A code, even if inspired by Shari'ah, is not Shari'ah-a code is simply a set of positive commandments that were informed by an ideal

50. Id. at 93-94. 
but do not represent the ideal. In my view, human legislation or codifications, regardless of their basis or quality, can never represent the Divine ideal. As to the fundamental rights that often act as the foundation of a constitutional system, a Muslim society must explore the basic values at the very core of the Divine Ideal. It would seem to me that the five juristic core values of protection for religion, life, intellect, honor, and property are a good starting point. ${ }^{51}$

And so it goes with most scholarship on Islamic law in US legal academia. In a patterned argument that repeats the Islamic law course syllabus, the scholar makes an elaborate effort to study the historic medieval text as the source of the truly Islamic, eliding over or cursorily dismissing the contemporary legal as inauthentic or transitory, only to bring us back to the contemporary through the backdoor by arguing that Islamic law can only be human! If this were only one of the ways in which Islamic law scholarship is represented in the US, this particular approach would be an interesting one. But the fact that, as I argue in this article, it dominates the scholarship and in this departs to a great extent from the dominant legal scholarship in the Islamic world itself is indeed what makes this phenomenon worthy of commentary and to secular Muslims like myself a source of alarm!

\section{Muslim Law vs. Law of Muslim Countries: Comparative LEGAL SCHOLARSHIP}

In this section I will argue that a desire parallel to that of Islamic law scholars to relegate the legal transplant of the Islamic world to a theoretical black hole also exists on the part of Western legal comparatists. I will take as example the writings on Islamic law of two comparatists: the French legal comparatist, René David, and the Italian comparatist Ugo Mattei. I choose David for his status as one of the most influential theorists of the idea of "legal families" in both the continent and the US. I choose Mattei because he belongs to a new, critical, and increasingly influential school of comparative law, the Sacco school of comparative law. ${ }^{52}$ In my discussion of both David

51. Id. at 101 .

52. In a commentary entitled One Hundred Years of Comparative Law, Rodolfo Sacco, the originator of the school, explains his insights on comparative law in the following way:

[W] have contrasted legal definitions, legal and doctoral declamations, and rules declared by the courts, with those rules effectively applied by the courts. We have also discovered that the circulation of law is more the circulation of diverse formants than the circulation of existing and working rules devoid of any contradiction within the system studied. The formants are disassociated. Here, comparative analysis offers the key to a better understanding of each of the national laws. Comparative law enables us to realize that a single written rule will have multiple applications. This multiplicity means 
and Mattei, I explore their respective attempts to find a legal family to adopt that "very different law" that typifies Muslims. ${ }^{53}$

Grouping legal systems in legal families, on the basis of some perceived commonality, is an old preoccupation of comparative legal literature in the West that has been critiqued and rejected by some while reconstructed on different grounds by others after taking the critique into account.

\section{René David}

In his attempt to find a legal family for the law of Muslims, René David confronts the historical difficulty generated by European colonization in the Islamic world in which "Muslim Law" (Islamic law) is not only altogether different from "Law in the Muslim countries" (legal transplant), but the latter clearly belongs to Western law (Romano-Germanic or Common law). More specifically, for David, the difficulty is how to eject the laws associated with Muslims from the Western family of laws, on the basis of Muslims' unbridgeable (philosophical ?) difference when their positive laws are in fact Western. In the course of relegating Muslims' law to the family of "other systems," David ends up not so much ignoring the legal transplant, as Islamic law scholars have a tendency to do, but speaking of the transplant as if it's an orphan child with special travails in the Islamic world different from those it experienced in other places (such as say Latin America). While David imagines the legal transplant in Latin America to have been adopted by jurists who have embraced and protected it from the alien society it traveled to, David doesn't seem to have a similar faith in the fate of the transplant in the Islamic world. The latter is imagined by him as having arrived in the Islamic world only to receive a hostile reception by Muslim jurists. Alone without protectors or believers among the Islamic jurist class, it finds itself

that a non-written element exists between the legal source and its interpretation, or it proves that a written rule does not have the force that would be necessary to replace an old customary rule. Law cannot be reduced to a written formula. Unwritten elements exist between the written formula and the law-fragments of old customs, that play a role in the mentalities of jurists; information that is communicated verbally at school and is, perhaps, wholly unverified; attitudes rooted in religious or secular ethics; latent notions in the culture of the interpreter. In sum, a whole world of elements exist that play a role in the law and about which we speak with respect to the means of legal interpretation. Comparative analysis has revealed them and has thereby unveiled the unwritten elements of the law, the "cryptotypes."

75 Tul. L. REv. 1159, 1169 (2001).

53. One that is different from Western Law, which for David includes the Romano-Germanic Law, the Common law, and Socialist Law. "In the [Romano-Germanic family and the Common Law family], the law has undergone the influence of Christian morality and, since the Renaissance, philosophical teachings have given prominence to individualism, liberalism and personal rights. Henceforth, at least for certain purposes, this reconciliation enables us to speak of one great family of western law.” David \& BRIERLEY, supra note 8, at 25. 
orphaned and embattled. Curiously, ignoring the jurist class identified with the transplant in the Islamic world has a similar effect to that of ignoring the transplant itself. The effect is the production of the transplant as always-about-to-be-Islamicized, indeed that it will surely have to be Islamicized. ${ }^{54}$

At first blush, what David calls "Muslim law" is easily distinguishable from "Western law" according to the very criteria that David sets out at the beginning of his book for classifying law into legal families. To determine according to David whether two laws belong to the same family, two considerations have to be taken into account. The first, the easy "translatability" of a law belonging to one legal culture to a student of law of another legal culture, and second, the similarity (or difference) of the underlying "philosophical, political or economic principles" of these two respective legal cultures. For David, these two criteria "must be used cumulatively, not separately."55

Muslim law clearly does not qualify for entry into the union of Western law according to the above criteria. It is neither easily translatable to a student of common law or civil law and due to its nature as religious law it is relegated by David to a different philosophical regime from that of the Western legal family.

The fundamental principle of Islam is that of an essentially theocratic society, in which the state is only of value as the servant of revealed religion. Instead of simply proclaiming moral principles or articles of dogma to which Muslim communities would have to make their laws conform, Muslim jurists and theologians have built up a complete and detailed law on the basis of divine revelation-the law of an ideal society which one day will be established in a world entirely subject to Islamic religion. ${ }^{56}$

By contrast, according to David, Western law has been influenced by "Christian morality and, since the Renaissance, philosophical teachings [that] have given prominence to individualism, liberalism and personal rights." 57 In other words, while Muslim law is foundationally religious, relying on holy sources for its articulation, Western law has never been religious per se, though historically influenced by Christian morality. Moreover, in its more recent past Western law has become philosophically liberal. The reference to the Renaissance, to my mind, is designed to assert Western law's essentially secular nature.

54. Id. at 482 .

55. Id. at 21 .

56. Id. at 455-56.

57. Id. at 25; see supra note 53. 
While Muslim law, as religious law cannot claim membership in a Western legal family, this is not easily the case with the contemporary positive laws of Muslim countries. For after all, these are nothing but transplants of Western laws.

By dividing his discussion of the topic into two sections: Muslim law and law of Muslim countries, and by ensuring not to collapse the one into the other or to treat the latter cursorily, in the way Islamic law instructors do, David seems to pay homage to the legal transplant in a serious way. Indeed, he is attentive to the ways in which the arrival of the legal transplant has complicated significantly the legal scene in Muslim countries. Not only has Muslim law been abandoned as governing law in fields such as contract, property, tort, crime, etc, but the one field that has retained Muslim law, personal status, has undergone codification in a great number of countries to the effect of transforming its very legal nature. Moreover, David is perfectly aware that courts associated with religious law have either been abolished through merger with non-religious courts or transformed by being forced to adjudicate on the basis of a code. ${ }^{58}$

For David, interestingly, religious law should be distinguished from the positive laws of Muslim countries even before the advent of the legal transplant. Not only is Muslim law as described in the above quote hardly present in the contemporary Islamic world as governing law, ${ }^{59}$ in fact, it has historically, and even before the advent of the transplant, always accommodated laws that were outside of its purview. This, Muslim law achieved through being conceptually open to customary practices, administrative legislation by the rulers, the creation of an infinite number of contractual arrangements due to its openness to the principle of "freedom of contract," and the use of legal stratagems and fictions by Muslim jurists to avoid the strictness of religious law. ${ }^{60}$ In fact it is precisely because of this conceptual accommodation of secular law that it had historically been possible for Muslim rulers to rationalize transplanting codes from Europe. ${ }^{61}$ In other words, David suggests that there has always existed a chasm in the Islamic world between religious law as ideal law (sometimes he likens it to natural law) and applied law as positive law. This duality has always been an integral part of the system.

58. Id. at $475-81$.

59. David states:

From Morocco to Indonesia, from the Soviet Socialist Republics of Central Asia and from Albania to Zanzibar and Guinea, over 500 million Muslims make up the majority of the population in some thirty countries, and they constitute large minorities in others. None of these countries is exclusively governed by Muslim law. Although its authority is proclaimed in principle, custom and legislation have everywhere added to or derogated from it. Id. at 473 (emphasis added).

60. Id. at 466-72.

61. Id. at 475 . 
However, the integral secularity of law otherwise conceived as religious does not lead David to understand Muslim law according to this inherent complexity. By insisting on the religious nature of Muslim law as the above quote reveals, David seems to treat the religious aspect of law as having a larger normative power than the secular aspect. For after all when he searches to find a quality to attribute to Muslim law, the one he adopts is that of "religious." David appears thus to treat religious law as a form of "natural law" that supercedes in its normative power secular (customary or administrative) regulation that take place under its purview. This view he attributes to Muslims:

In Muslim countries . . . more attention is given to the model law linked to the Islamic religion than to local custom (treated as a phenomenon of fact) or the laws and decrees of the sovereign (treated as merely administrative measures) and neither of these is thought to possess the full dignity of law. ${ }^{62}$

Indeed, when trying to explain to his Western readers the nature of Muslim law David evokes the parallel to the idea of "natural law" in Western thought as a way of making it familiar to them. ${ }^{63}$

So when we ask ourselves, why does not David welcome the laws of Muslim countries as "foster children" of Western law? The answer is his belief that while Muslim law as religious law might not be in the books, in the courts, in the classroom, it's over there above everybody's head speaking natural law to positive law. And since no Muslim law speaks above the head of Westerners, Muslims could not be treated as foster children. At best, they can be seen as distant cousins, for after all, we Westerners, are familiar with the idea of natural law and some of us do still indeed advocate it.

To treat laws of Muslim countries as part of the family of Western law would undermine a basic premise of David's comparative methodology and its sociological assumptions. For David, law has a double quality: it both stems from society, including its peculiar economic, social and political circumstances, and at the same time expresses this society's ideals. Laws might be substantively and formally different in two countries but the similarity in their sociological circumstances and respective ideals, relegate their laws to the same family. David therefore insists that:

[T] hese three families of law [Romano-Germanic, Common, and Socialist] are closely linked to the development of European civilisation. They reflect a way of thinking and living which is western; they express ideas and embody institu-

62. Id. at 28 .

63. Id. 
tions which have been formed in the European cultural and historical context. Their adoption in America offered almost no difficulties because no indigenous civilisation could rival them. The only problem was their adaptation to a different geographical milieu. ${ }^{64}$

So why might we treat American law as part of Western law when the Americans adopt a European legal transplant but not do the same with Muslim countries? Answer, when European law traveled to the Muslim world, it encountered a rival civilization, one that is not only legal, but also highly legalistic. So one might succeed in uprooting the law of a given civilization as happened in Muslim countries, however a whole civilization with its accompanying ideas and institutions cannot be similarly uprooted. A foreign law might "check in" but, sooner or later it will be haunted by the "ideas and institutions" of the new/old "world," those parallel to the ones it left behind. Moreover, those ideas and institutions feeling deprived of their own law, the one they have sociologically produced, will haunt the new law with demands for reincarnation, local performance, or alternatively, demise. Such is the logic of law if it is to be seriously grounded in social reality and the oeuvre of a particular civilization.

Thus David declares:

A new branch of law based on modern percepts may very well be accepted with the adoption of western concepts; there maybe more or less significant deviation from the basic orthodox rules, even to the point of secularising and repudiating the fundamental concepts of Muslim law. Nevertheless, the law of Muslim countries will still not be completely assimilated into the Romanist family-or at least not for a great many years to come. Apart from any purely legal consideration, jurists in Muslim countries will cling to their traditional ways of arguing and thinking for a long time to come; these are the ways of the society in which they live. If all trace of Muslim legal tradition is to be wiped out, not only the law but the whole of society will have to be altered. In fact, the entire Islamic civilisation would have to be rejected. ${ }^{65}$

In a "multicultural move" that echoes David's liberal ideology, he concludes that given that western law will inevitably have to be "synthesized, in some way relatively acceptable to the orthodox point of view, with methods of reasoning and an outlook moulded by the tradition of Muslim law," the study of Muslim law from the comparative law perspective will have to be pursued for a long time to come. ${ }^{66}$ So what

64. Id. at 453 .

65. Id. at 482 .

66. Id. at 483 . 
appeared at first to be an irrational repudiation of the law of Muslims from the family of Western law of which it originated, turned out to be no more than respect for civilizational ontological difference. We have our history they have theirs; we have our ideals they have theirs, even if our law overtakes theirs that does not mean they become us. For they have a difference which is unbridgeable even with the commonality of law between us.

Interestingly, when David confronts a similar situation in Latin America he handles it quite differently. There too European law traveled to an altogether different place, an altogether different society. In fact, David is struck when it comes to Latin America by the gap between the advanced European law adopted by the European elites of Latin America and the primitiveness of the society in which these laws are applied. There too one finds a chasm between law and society in which it couldn't be claimed that the former is an expression of the latter. Yet that does not dissuade David from welcoming Latin American law into the warm embrace of the Western family of laws.

Why? Because, unlike jurists in Muslim countries who according to David "will always cling to their traditional ways of arguing and thinking for a long time to come," David is able to identify with Latin American jurists as essentially European, like David himself. This presumption of European-ness allows David to put his trust in those jurists and to think of them as loyal to Europe and European ways, trustworthy in their ability to embrace European law and to inject it in their own primitive societies in a way that doesn't necessarily transform European law (as Muslims would inevitably do) but to merely particularize it according to local social circumstances. ${ }^{67}$

What is peculiar is that while David's discussion of law of Muslim countries seems relatively informed, his sociological comprehension of Muslim jurists leaves a lot to be desired. While David acknowledges the power of the transplant in Muslim countries including its displacement of religious law, he however seems to imagine that the transplant traveled magically without a Muslim jurist elite that would have piloted it into place, ushered it in, hosted it, developed it, accommodated it, identified with it, and went into serious battle with religious jurists to defend its right of place. Oddly for David, while law has replaced law, jurists have not replaced jurists. The legal transplant in the Muslim world, unlike its equivalent in Latin America, is an orphan child with blond hair and blue eyes and no parents to claim.

David's sense of estrangement from the secular jurists of the Islamic world is the more striking given that a large number of them

67. All the arguments that I make pertaining to David on Latin America I have learnt reading Jorge L. Esquirol, The Fictions of Latin American Law (Part I), 1997 UTAH L. REV. 425. 
have been educated by David's mentor (Edward Lambert) of the Comparative Law Institute de Lyon, and deeply influenced by the school of scientific jurisprudence that had had a great deal of influence on David himself (Genie, Salleille, Duguit)! How can David relegate them to conceptual darkness when they are his intellectual comrades? Perhaps David finds it socially impossible for Muslims to share his ideals! If he did, then he might be forced to rethink his civilizational divisions, no matter how charitable they might have been in the first place.

So while David pays homage to the transplant, he ignores its jurists. Since therefore the transplant is imagined alone without any protectors, it will have to become "Roman like the Romans" if it wants to survive. It will have to give up being itself if it wants to be. A move familiar in Islamic law course descriptions and scholarship.

\section{Ugo Mattei}

In an attempt at avoiding the pitfalls of René David's approach to legal families, Ugo Mattei wrote a recent article proposing his own approach to the subject of legal families. ${ }^{68}$ One of the primary aims of this new approach, as Mattei explains, is to re-center in comparative law what has been conventionally called "radically different cultures"69 or what René David calls "other [legal] systems."70 Mattei is proposing a model of categorization that aspires to more accuracy through incorporating a more complex understanding of legal systems especially their multi-layered quality. One of the things that Mattei wants to emphasize is that the common law and civil law legal systems are "everywhere." And so in a sense, every legal system is potentially a member of the Davidian Western legal family.

However, Mattei proposes that there are other factors that influence categorization in one family or the other depending on the hegemony, in the practice of law in a particular country, of a certain set of factors. He describes those factors, following Weber, as constraints (of individual behavior) and he divides them into: the political, the traditional, and the legal. ${ }^{71}$ So according to this typology there are countries, despite the presence of the Western legal transplant, where the practice of law is dominated by tradition, others by politics and others where the practice of law takes place so to speak "inside the law," i.e. dominated by legal technicalities, procedures and legal jargon. For Mattei therefore, a country might fall either under the rubric of "traditional law," "political law" or "professional law."

68. Mattei, supra note 9.

69. Id. at 60 .

70. DAVID \& Brierley, supra note 8 , at 27.

71. Mattei, supra note 9 , at 8. 
I find Mattei's model to be very useful due to its attempt to capture the complexity of legal practice in different countries. This model as I see it, allows recognition of professional law in a particular country but would also propose to categorize this country as a member of the "political law family" because it's professional law practice is subject to political hegemony (ex. Rulers influence and/or control judges) or alternatively a member of the "traditional law family" because of the hegemony of extra-legal norms and authority figures on legal practice (the local "Mufti" influences the way people behave more than the Franco-phone judge manning the civilian court). Moreover, according to this model one may even divide the legal practice in one country into particular fields, so its commercial life might be practiced "professionally," its public law "politically," its family law "traditionally."

The problem is that despite the complexity of Mattei's model and its great descriptive potential, it's hard to ignore the observation that Mattei, especially when delineating the difference between the "West" and the "East" when it comes to law, ends up reproducing David's earlier categorizations. As such, the European civilian and common law countries belong to the family of "professional law" (previously Western legal family), the Islamic countries, China and Japan belong to that of "traditional law" (previously "other legal systems"). One may introduce novel notions such as "hegemony" and "multiple constraints" but the East is still the East (victim to tradition) and the West is still the West (faithful to "the rule of law"). Moreover, it's hard to escape the implicit "normative" effect of the classification: rule of law, is better than tradition, any minute of the day. Who wants to live in the latter? In fact, the universal impulse is that if you want yourself "civilized," you absolutely must de-center tradition, and re-center whatever "rule of law" you might have. Law is a Western gift to East's (hopefully dying) tradition. Get professional!

More importantly though, and in a move that both repeats René David's insistence on the surviving normative power of Islamic law as religious law despite its replacement by the legal transplant and also mimics the "Islamic law supremacy" of Islamic law instructors and scholars, Mattei gives "traditional law" in the Islamic countries a supra-normative power by insisting on its hegemony as a form of legal practice. Indeed, as one reads on, one notices that for Mattei the word "Muslim" evokes "traditional law" in an associative manner, so much so that he only feels the need to refer to the "large Muslim population"72 in India (among other reasons) to make the point that Indian law should be considered a member of the "traditional law" family.

72. Id. at 12 . 
While Mattei's categories are more complex than those of David, and therefore invite a more complex investigation of legal phenomena, when it comes to the Islamic world, Mattei does no such thing. In fact he seems to pay homage to the "traditional law" of comparative legal literature that espouses the wisdom that law in the Islamic world has got to be "traditional." If Mattei took seriously the combination of the legal transplant and the nature of the contemporary nation state in the Islamic world, he would have seen that an accurate deployment of his own categories, would lead him to a more complex categorization of law in the Islamic world. For instance, and using Mattei's approach, I would argue that in most Muslim countries' law could be characterized as "political" when it comes to public law (just like Latin America), "professional" when it comes to commercial law (also like Latin America), and "traditional" when it comes to family law. The fact that most Muslims live in authoritarian or pseudo-democratic nation states is to my mind far more relevant to our characterization of law in these countries than the fact that these Muslims contract their marriages and divorces following Islamic family law. In that respect, Muslims share a great deal in common, in terms of the predicament of law in their countries, with equally situated Latinos, Africans and Asians.

Once we have located law inside the nation state (and not on the shoulders of Muslims) we can then inspect legal phenomenon with the help of Mattei's categories by being attentive to the exact distribution of professional law and political law in a particular state. It is perfectly conceivable that, in one authoritarian state, "political law" would overwhelm and control other practices of law, such as ones related to commerce, corporations, investments, land-tenant law, but then it might not. That depends on how "corrupt" the state is. So a country, Muslim, Latino, or African, might indeed belong to "political law" when it comes to say administrative and constitutional law, but be described as "professional" when it comes to criminal law (except when it comes to political opposition), "professional" when it comes to commercial law and land-tenant law but "political" when it comes investment law, etc. It all depends on how stable or unstable the particular regime is, how much support it had marshaled among its middle class, its commercial and business class, what the grounds of legitimacy for its continuity are, etc.

This all leads to the conclusion that "packaging" the Islamic world in this manner and describing its law as traditional because it simply has residues of religious law is not only wrong but un-insightful. Tradition and traditional law do not have much explanatory power in the Islamic world (and perhaps nowhere else for that matter). Leaders of Muslim countries might resort to "tradition" to beef up their legitimacy, as Mattei points out, but that translates into he- 
gemony of the political over the traditional not vice versa. Tradition is being used and manipulated, not succumbed to. What signifies political leadership in the Islamic world, at least the majority of it, is not that it submits to tradition, but that it uses tradition to legitimize its demand that the citizens of the state submit to the state's coercive power, its non-law.

A concrete study of specific national legal systems and the function they perform within authoritarian nation states get us into the first step on the path to accurate description of law in the Islamic world.

\section{Conclusion}

Giving Islamic law an overarching status analytically in our approach to law in the Islamic world, distorts our understanding of legal phenomena in these countries. Islamic law should be approached as one, but only one, of the constitutive elements of law that has not only been de-centered by the transplant but also transformed. Not only have its rules been reformed, but also its modes of reasoning, and its jurist class. Its treatises have been turned into codes, and its qadis turned into modern judges. Moreover, its internal conceptual organization, has been transformed by being reduced to a rule structure positivized in a code and dependent on state enforcement. Consequently, its normative hold over people has changed. Islamic law is now largely "privatized" in voluntary acts of ritual and worship and consultation with religious figures as to how to treat one's wife and the religiously acceptable way to invest one's money. In other words, and as Talal Al-Assad argues in Formations of the Secular, ${ }^{73}$ a separation between law and morality, religion being relegated to the latter, has entered the Islamic world and has cut off the continuous, normative and juridical hold Islamic law had had on Muslims, covering the whole spectrum of one's life-acts. Islamic law seems to have been itself transplanted: from the past to a present it hardly recognized and therefore had to change to accommodate.

As for the transplant itself, its familiarity should not blind us. Perhaps it is time that we approach it with the same tools, paradigms, and theoretical framework as we do Western law. The reciprocal desire, between Islamic law scholars and Western comparatists, to self-exoticize on the one hand and to exoticize on the other, to relegate law to Islamic law in the Islamic countries, should be resisted.

Baudouin Dupret in an essay surveying recent French literature on law in the Arab world describes one such attempt at resisting the

73. Talal Al-Assad, Formations of the Secular: Christianity, Islam, ModerNITY (2003). 
paradigm of "Islamic law."74 The study he describes is entitled The Supreme Constitutional Court of Egypt and the Protection of Fundamental Rights. He writes:

This is a purely legal analysis of the case law of the Supreme Constitutional Court of Egypt concerning public freedoms. It provides a complete introduction to the court, its adjudication and the normative role of the judge in his interpretation. It also raises the question of the relationship between the constitutional judiciary and its political environment. But its main value comes from the fact that it deals with an Arab judicial institution within the same aims and tools as those used for studying the American Supreme Court or the French Conseil constitutionnel. This kind of legal work has set the standard for future research in the field. It should be considered as a compulsory prerequisite to research on the socio-political dimension of Arab law in any context. ${ }^{75}$

A step in the right direction.

74. Baudouin Dupret, Modern Law and Arab Societies in Recent French-Speaking Literature, 15 J.L. \& RELIGION 289 (2000).

75. Id. at 295. 